\title{
Chikungunya Virus in City
}

\author{
Fakhsheena Anjum ${ }^{1 *}$, Lubna Bashir ${ }^{2}$, Shazia Naz $^{2}$ \\ ${ }^{1}$ Dow College of Pharmacy, Dow University of Health Sciences, Karachi, Pakistan \\ ${ }^{2}$ Faculty of Pharmacy, Federal Urdu University of Arts, Science and Technology, Karachi, Pakistan
}

\begin{abstract}
"Chikungunya", comes from the Kimakonde language, meaning "that which bends up". This name was given owing to the stooped posture causingpain (arthralgia) [1, 2]. Chikungunya had first outbreak in southern Tanzania in 1952. The virusis a single stranded (genus alpha); RNA virus belonging to the family Togaviridae [3]. This virus is transferred to humans through daytime biting mosquitoes. The precise mechanism of access of this virus into mammalian cells is still under research $[4,5]$. Most of the investigation has been from the Asian countries.
\end{abstract}

Chikungunya is a self-remitting febrile disease [6]. This disease can be misdiagnosed with zika and dengue because it shares some clinical symptoms particularly in areas where they are common. No cure for the disease exists yet; therapy is to relieve the symptoms. It has been established that the vicinity of mosquito breeding locations to human inhabitation is a substantial risk factor for chikungunya disease [3].

The arthralgia due to chikungunya can remain from months to years in some people and may advance to frank arthritis in certain affected individuals [7-10]. Therefore the virus can cause acute, subacute or chronic illness; mostly patients get well completely [3]. Chikungunya virus does not cause neurovirulent or neuro-invasive disease which is distinct from other alpha viruses; coinfection of Chikungunya with dengue was reported from Yemen [11, 12]. Hemorrhagic signs are infrequent with Chikungunya fever unlike dengue fever, and if existing, they are generally mild i.e. epistaxis, gingival bleeding, etc. Complications due to the disease had been frequently reported in infants, adults with comorbidities, and aged patients [13-15].Intrauterine infection with vertical transmission in pregnant women was also reported [16, 17]. Several Chikungunya cases have been reported mostly in Africa, Asia and the Indian subcontinent; though a major epidemic affecting numerous countries of the Americas in 2015 had also been reported [3].

Reports from the Pakistan Ministry of National Health Services showed over 1,000 cases of Chikungunya cases in the Karachi city since December 2016 with no deaths so far. Various healthcare agencies in Karachi have assessed the total number of affected individuals by Chikungunya to be more than 30,000.The epidemic is assumed to be due to the year's warm winter in Karachi city that enabled the Aedes mosquito to flourish in the mild temperatures. Additionally, the meager sanitation structure in Karachi city is an excellent breeding setting for mosquitoes. Overall 1,018 doubted Chikungunya cases were informed in the Karachi city from 19-12-16 to 30-03-17.There were 121 positive samples out of 157 for Chikungunya virus that were sent to the National Institute of Health (NIH) in Islamabad [18-20].

The prevention and control on Chikungunya is possible by decreasing the natural and artificial waterfilled container habitations that upkeep breeding of the mosquitoes. During epidemics, insecticides may be used and water be treated in containers for killing the immature larvae. For protection, clothing minimizing skin exposure during day time is recommended; application of repellents to exposed skin or to clothing in stringent accordance with product label directions is also advised [21].

Regarding the official response to the outbreak in Karachi, the district and town health officers were instructed in opting preventative measures against Chikungunya fever in the city. Since no vaccine is available currently against the disease for prevention, treatment is mainly supportive to relieve pain and fever. Some individuals or travellers are at higher risk of the virus to contract Chikungunya. They 
include: persons over 65 years of age, those having arthritis, those having certain medical disorders like high blood pressure, heart ailment or diabetes, women who are shortly due to give birth, owing to the risk the virus presents to babies born when their mother is showing symptoms of the virus, those spending much time outdoors, those working and/or living in areas without window screening or air conditioning which may help decrease the risk of mosquito bites [18-20]

Diagnosis for chikungunya can be made by serological tests, such as enzyme-linked immunosorbent assays (ELISA), confirming the existence of IgM and IgG anti-chikungunya antibodies and also virological techniques (RT-PCR).Various reverse transcriptase-polymerase chain reaction (RT-PCR) approaches exist but they are of inconstant sensitivity. RT-PCR products may also be used for genotyping of the virus from clinical samples [3]. Antiviral treatment for Chikungunya infection is under research. Molecules inhibiting Chikungunya viral replication by direct inhibition of the virus or that act through host defense mechanisms have been acknowledged [22].

Dissimilar strains of Chikungunya virus have been reported from various regions within variable transmission cycles; these cases demonstrate the extent of the universal spread of Chikungunya disease. Maintenance of well-organized surveillance systems and application of ample prevention methods to contain the infection and to avoid epidemics is highly required.

\section{REFERENCES}

[1] Robinson MC. An epidemic of virus disease in Southern Province, Tanganyika Territory, in 1952-53. I. Clinical features. Trans R Soc Trop Med Hyg. 1955;49(1):28-32. 10.1016/00359203(55)90080-8 [PubMed] [Cross Ref]

[2] Lumsden WH. An epidemic of virus disease in Southern Province, Tanganyika Territory, in 1952-53. II. General description and epidemiology. Trans R Soc Trop Med Hyg. 1955;49(1):3357. 10.1016/0035-9203(55)90081-X [PubMed] [Cross Ref]

[3] Chikungunya. Fact sheet Updated April 2017; WHO

[4] Teo TH, Lum FM, Claser C, Lulla V, Lulla A, Merits A. A pathogenic role for CD4+ T cells during Chikungunya virus infection in mice. J Immunol. 2013. Jan 1. 190(1):259-69. [Medline].

[5] Teo TH, Lum FM, Lee WW, Ng LF. Mouse models for Chikungunya virus: deciphering immune mechanisms responsible for disease and pathology. Immunol Res. 2012 Sep. 53(1-3):13647. [Medline].

[6] Suganthini KN, Michael SB. Chikungunya Virus. Drugs \& Diseases > Infectious Diseases. Updated: Oct 27, 2016

[7] Gérardin P, Fianu A, Malvy D, et al. Perceived morbidity and community burden after a Chikungunya outbreak: the TELECHIK survey, a population-based cohort study. BMC Med.2011; 9: 5. 10.1186/1741-7015-9-5 [PMC free article] [PubMed] [Cross Ref]

[8] Moro ML, Grilli E, Corvetta A, et al. Long-term chikungunya infection clinical manifestations after an outbreak in Italy: a prognostic cohort study. J Infect. 2012. 65(2):165-72. 10.1016/j.jinf.2012.04.005 [PubMed] [Cross Ref]

[9] Mohd Zim MA, Sam IC, Omar SF, et al. Chikungunya infection in Malaysia: comparison with dengue infection in adults and predictors of persistent arthralgia. J Clin Virol.2013. 56(2):141-5. 10.1016/j.jcv.2012.10.019 [PubMed] [Cross Ref]

[10] Thiberville S, Boisson V, Gaudart J, et al. Chikungunya fever: a clinical and virological investigation of outpatients on Reunion Island, South-West Indian Ocean. PLoS Negl Trop Dis.2013. 7(1):e2004. 10.1371/journal.pntd.0002004 [PMC free article] [PubMed] [Cross Ref]

[11] Rezza G, El-Sawaf G, Faggioni G, Vescio F, Al Ameri R, De Santis R. Co-circulation of Dengue and Chikungunya Viruses, Al Hudaydah, Yemen, 2012. Emerg Infect Dis. 2014. Aug. 20(8):1351-4. [Medline].

[12] Nimmannitya S, Halstead SB, Cohen SN, Margiotta MR. Dengue and chikungunya virus infection in man in Thailand, 1962-1964. I. Observations on hospitalized patients with hemorrhagic fever. Am J Trop Med Hyg. 1969. Nov. 18(6):954-71. [Medline].

[13] Gerardin P, Samperiz S, Ramful D, Boumahni B, Bintner M, Alessandri JL. Neurocognitive Outcome of Children Exposed to Perinatal Mother-to-Child Chikungunya Virus Infection: The 
CHIMERE Cohort Study on Reunion Island. PLoS Negl Trop Dis. 2014. Jul. 8(7):e2996. [Medline].

[14] Lewthwaite P, Vasanthapuram R, Osborne JC, et al. Chikungunya virus and central nervous system infections in children, India. Emerg Infect Dis. 2009. Feb. 15(2):329-31. [Medline]. [Full Text].

[15] Das T, Jaffar-Bandjee MC, Hoarau JJ, et al. Chikungunya fever: CNS infection and pathologies of a re-emerging arbovirus. Prog Neurobiol. 2010. Jun. 91(2):121-9. [Medline].

[16] Gerardin P, Barau G, Michault A, et al. Multidisciplinary prospective study of mother-to-child chikungunya virus infections on the island of La Réunion. PLoS Med. 2008. Mar 18. 5(3):e60. [Medline]. [Full Text].

[17] Lenglet Y, Barau G, Robillard PY, Randrianaivo H, Michault A, Bouveret A. [Chikungunya infection in pregnancy: Evidence for intrauterine infection in pregnant women and vertical transmission in the parturient. Survey of the Reunion Island outbreak]. J Gynecol Obstet Biol Reprod (Paris). 2006. Oct. 35(6):578-83. [Medline].

[18] Pakistan chikungunya tally tops 1,000, Outbreak. News Today, 18 April 2017

[19] Mahd R, Fatima-tuz-Zahra, Sabia M, Azra M, Shameem B. Outbreak of chikungunya in Pakistan. The Lancet 2017. March Vol 17

[20] Chikungunya: Asia (Pakistan), ProMED mail, Archive Number 20170420.4978219, 20 April 2017

[21] Chikungunya virus cases spark fears of outbreak in Karachi. Samaa Web Desk; Published in Health, Pakistan 2016.December 18

[22] Abdelnabi R, Neyts J, Delang L. Towards antivirals against chikungunya virus. Antiviral Res. 2015 Sep. 121:59-68. [Medline]. 